\title{
Uncoupling protein-3 gene expression: reduced skeletal muscle mRNA in obese humans during pronounced weight loss
}

\author{
H. Esterbauer ${ }^{1}$, H. Oberkofler ${ }^{1}$, G. Dallinger ${ }^{1}$, D. Breban ${ }^{1}$, E. Hell ${ }^{2}$, F. Krempler ${ }^{3}$, W. Patsch ${ }^{1}$ \\ ${ }^{1}$ Department of Laboratory Medicine, Landeskrankenanstalten Salzburg, Austria \\ ${ }^{2}$ Department of Surgery, Krankenhaus Hallein, Austria \\ ${ }^{3}$ Department of Internal Medicine, Krankenhaus Hallein, Austria
}

\begin{abstract}
Aims: Uncoupling protein-3 is a member of a protein family that serves to dissipate energy in the form of heat thereby modulating energy expenditure. Alternative processing of uncoupling protein-3 transcripts results in two mRNA species that encode a large and small protein, perhaps differing in functional activity. Since obesity is associated with disrupted energy homeostasis, we measured muscle mRNA expression in morbidly obese and lean subjects.

Methods: The two uncoupling protein-3 mRNA species were quantified in muscle tissue using an RNase protection assay. Gene locus effects on mRNA expression were studied by quantitative allele-specific primer extension.

Results: In both obese and lean subjects, the mRNA species encoding the small protein isoform was twice as abundant as the mRNA species encoding the large protein isoform. Neither the total uncoupling protein-3 mRNA expression nor the molar abundance ratios of the two mRNA species differed between
\end{abstract}

obese and lean male or female subjects. Women who had lost $37 \pm 22 \mathrm{~kg}$ of weight in response to dietary restriction and continued a hypocaloric diet displayed lower mRNA than obese $(p<0.005)$ or lean women $(p<0.05)$. Primer extension assays in lean and obese subjects showed similar allelic mRNA abundance in all but one subject studied.

Conclusion: Muscle expression of the two uncoupling protein-3 mRNA species is similar in obese and lean people. In obese patients, prolonged hypocaloric diet downregulates uncoupling protein-3 mRNA expression in muscle and can thereby enhance its energy efficiency. Sequence substitutions at the gene locus may only be minor determinants of mRNA expression in muscle tissue. [Diabetologia (1999) 42: 302309]

Keywords Obesity, genetics, uncoupling protein-3, gene expression, skeletal muscle.
Obesity, the most common nutritional problem in Western societies, is caused by a sustained imbalance of food intake and energy expenditure. A long-term

Received: 8 July 1998 and in final revised form: 23 November 1998

Corresponding author: W. Patsch, M.D., Department of Laboratory Medicine, Landeskrankenanstalten Salzburg, Muellner Hauptstrasse 48, A-5020 Salzburg, Austria

Abbreviations: UCP1, Uncoupling protein-1; UCP2, uncoupling protein-2; UCP3, uncoupling protein-3; UCP3 and $\mathrm{UCP}_{\mathrm{S}}$, large and small forms of uncoupling protein-3; BAT, brown adipose tissue; RT, reverse transcription; OD, optical density. reduction in energy dissipation could therefore be a predisposing factor for this disorder. Indeed, a decrease in the resting metabolic rate is a risk factor for obesity $[1,2]$ and genetic factors appreciably contribute to the magnitude of the basal metabolic rate $[3,4]$. Brown adipose tissue (BAT) is specialized for thermogenesis, a chief determinant of energy expenditure [5]. Central to BAT-function is the uncoupling protein-1 (UCP1) which stimulates heat production by uncoupling substrate oxidation from ATP synthesis [6]. Although the importance of BAT as a regulator of body fat stores has been established in rodents $[7,8]$, its role in human obesity is not clear because adult humans possess very little BAT [9]. Notwithstanding this qualification, considerably less mRNA 
of the BAT-specific UCP1 have been observed in the intraperitoneal adipose tissue of obese than in lean control subjects [10]. A contribution of UCP1 and BAT to energy expenditure in humans is therefore conceivable.

Two other recently discovered members of a mitochondrial carrier superfamily, UCP2 and UCP3, are more widely expressed in humans and in rodents. Uncoupling protein-2 mRNA is found in white adipose tissue, BAT, lung, liver, spleen and macrophages [11, 12] and high expressions of UCP3 mRNA are observed in skeletal muscle and BAT [13-15]. Although direct evidence for a thermoregulatory function of UCP3 has not been presented, this protein could be implicated in energy homeostasis because muscle tissue accounts for a large portion of catecholamine and diet-induced thermogenesis in both humans [16] and rats [17]. Both the human UCP2 and UCP3 gene have been mapped to chromosome 11q13 [12, 18, 19]. Linkage analysis in pedigrees of the Quebec Family Study provided strong evidence for an association of this chromosomal region with resting metabolic rate, body mass index (BMI) and fat mass in adult humans [20]. In addition, the syntenic region on mouse chromosome 7 is coincident with quantitative trait loci for obesity and Type 2 (non-insulin-dependent) diabetes mellitus [21,22].

In comparison with lean controls, UCP2 mRNA abundance was reduced in intraperitoneal adipose tissue of morbidly obese subjects and UCP2 mRNA expression remained low in post-obese subjects studied before and after weight reduction [23]. By contrast, UCP3 mRNA expression in muscle tissue did not differ between obese and lean subjects [24]. Unexpectedly, UCP3 mRNA expression increased after short-term fasting. Owing to alternative polyadenylation/splicing, UCP3 mRNA occurs in two isoforms termed $\mathrm{UCP}_{\mathrm{L}}$ and $\mathrm{UCP}_{\mathrm{S}}$ mRNA $[14,18]$. Because of a C-terminal truncation, $\mathrm{UCP} 3_{\mathrm{S}}$ lacks the sixth predicted transmembrane domain and a purine nucleotide binding domain implicated in nucleotide-mediated inhibition of UCP-activity [25]. Thus $\mathrm{UCP}_{3}$ could possess enhanced activity but faulty membrane insertion might compromise its stability and function. In a follow-up study, it was suggested that UCP3 transcript processing is not altered in obese people because using an RT-PCR method for quantification, equimolar abundance of $\mathrm{UCP}_{\mathrm{L}}$ and $\mathrm{UCP} 3_{\mathrm{S}}$ mRNA was found in muscle tissue of both obese and lean subjects [26].

To study the role of UCP3 in human obesity and energy metabolism, we quantified $\mathrm{UCP}_{\mathrm{S}}$ and $\mathrm{UCP}_{\mathrm{L}}$ mRNA expression in skeletal muscle of obese, post-obese and lean subjects by RNase protection assay and studied allele-specific expression in an attempt to identify mutations at the UCP3 gene locus that affect mRNA expression.

\section{Subjects and methods}

Study subjects, skeletal muscle and intraabdominal fat tissue samples. Tissue samples were obtained from musculus rectus abdominis of 38 morbidly obese subjects who underwent weight reduction surgical treatment through a gastric banding procedure. In seven of these subjects, muscle tissue was also obtained during an elective surgical procedure $9 \pm 5$ (means \pm SD) months after the gastric banding surgery. Fifteen control subjects and ten post-obese subjects, not sampled during the initial weight reducing surgery, underwent elective surgical procedures such as cholecystectomy, repair of hernias and adjustment or removal of the gastric tape. Study subjects gave informed consent and the study was approved by the institutional review board. After an overnight fast general anaesthesia was induced by a short-acting barbiturate and maintained by alfentanil-hydrochloride. Tissue biopsies were taken at the beginning of the surgical procedure, divided into aliquots and frozen at $-70^{\circ} \mathrm{C}$. Body mass index (BMI, kilograms per meter squared) was calculated from measurements of weight and height.

Clinical procedure. After an overnight fast, venous blood was collected into tubes containing EDTA. Plasma glucose was measured by a hexokinase/glucose-6-phosphate dehydrogenase method (Boehringer Mannheim Diagnostics, Mannheim, Germany). Plasma insulin was measured by immunoassay (MEIA, Abbott Laboratories, Abbott Park, Ill., USA). Plasma non-esterified acids were determined by an enzymatic colorimetric method (Boehringer Mannheim Diagnostics). Plasma leptin concentrations were measured with a RIA kit (Linco, St. Charles, Mo., USA).

Isolation of DNA and skeletal muscle and adipose tissue total $R N A$. We isolated Genomic DNA from peripheral leucocytes using the QIAamp Blood Kit (Qiagen, Hilden, Germany) and RNA from $0.5 \mathrm{~g}$ of human skeletal muscle according to a previously described method [27]. The integrity of RNA samples was ascertained by their electrophoretic pattern in formaldehyde gels. Concentrations of RNA were determined by absorbance measurements at $260 \mathrm{~nm}$.

Quantification of total $U C P 3, U C P 3_{S}$ and $U C P 3_{L} m R N A$ by $R$ Nase protection assay. Fragments of cDNA spanning exon 6 and 7 were amplified by RT-PCR. 5'-CCCCTGCCACTTTGTCTCTG-3' $3^{\prime}(+651$ to +670$)$ as sense and $5^{\prime}$-CACCGTTTTCTTCCATTCTT-3' (+ 1016 to + 1036) or 5'-TCCCTAACCCTCCCCATCAG-3' ( + 985 to + 1004) as antisense primers were used for $\mathrm{UCP} 3_{\mathrm{L}}$ and $\mathrm{UCP} 3_{\mathrm{S}}$, respectively. The numbers in parentheses designate the position of the primers relative to the translation start site (GenBank Accession Nr. U84763 for $\mathrm{UCP}_{\mathrm{L}}$ and U82818 for $\left.\mathrm{UCP} 3_{\mathrm{S}}\right)$. Fragments of PCR were cloned into pGEM3Zf $(+)$. We synthesized ${ }^{32} \mathrm{P}$-labelled antisense and ${ }^{3} \mathrm{H}$-labelled sense RNA using the Riboprobe Combination System-SP6/T7 (Promega Corp., Madison, Wis., USA) and $\alpha^{32} \mathrm{P}$-dUTP $(110 \mathrm{TBq} / \mathrm{mmol})$ or $\alpha^{3}$ H-dUTP (367 GBq/mmol; Amersham Life Science, Buckinghamshire, UK). In vitro transcribed RNA was gel purified and incorporated radioactivity was determined by liquid scintillation counting (Wallac 1450 Microbeta PLUS, EG\&G Berthold, Bad Wildbach, Germany). Aliquots of $8 \times 10^{4} \mathrm{cpm}$ of ${ }^{32} \mathrm{P}$ labelled RNA were hybridized either with $10 \mu \mathrm{g}$ total skeletal muscle RNA or, for assay standardization, with increasing amounts of ${ }^{3} \mathrm{H}$-labelled $\mathrm{UCP} 3_{\mathrm{L}}$ or $\mathrm{UCP} 3_{\mathrm{S}}$ sense RNA. After digestion with 0.5 units of RNase A and 20 units of RNase T1 (Ambion RPAII Kit; Ambion Inc., Austin, Tex., USA) at 
$37^{\circ} \mathrm{C}$ for $30 \mathrm{~min},{ }^{32} \mathrm{P}$-labelled RNA-RNA hybrids were precipitated, subjected to electrophoresis in $4 \%$ polyacrylamideurea gels and quantified by scanning of autoradiographs with a Model GS-700 Imaging densitometer using the Molecular Analyst software (Bio-Rad, Hercules, Calif., USA). Tissue UCP3 mRNA expression was calculated using a standard curve that was constructed by plotting signal intensities of ${ }^{3} \mathrm{H}-$ labelled $\mathrm{UCP} 3_{\mathrm{L}}$ or $\mathrm{UCP} 3_{\mathrm{S}}$ against the respective doses. We corrected UCP3 mRNA results for cyclophilin A [28] mRNA abundance determined by RNase protection assay using a 122 nt cyclophilin antisense probe spanning nucleotides +189 to +310 relative to the transcription start site (GenBank Accession Nr. Y00 052).

Allele-specific gene expression studies. Primer extension was used to quantify UCP3 mRNA transcribed from the wild-type and variant allele harbouring a $\mathrm{T} / \mathrm{C}$ substitution at position +297 relative to the translation start site [29]. To type the T/C substitution, genomic DNA was amplified by PCR using 5 '-TGGACTGAAGCCTTCAGACGTG-3' and 5'-ACAACAGTTCTGTAAACATGTG-3' ${ }^{\prime}(+159$ to +180 and +1189 to + 1207, Genbank Accession Nr. U84763) as sense and antisense primer. Reactions of PCR contained $0.2 \mu \mathrm{mol} / \mathrm{l}$ of each upstream and downstream primer, $200 \mu \mathrm{mol} / \mathrm{l}$ of dNTPs, $10 \mathrm{mmol} / \mathrm{l}$ Tris, $\mathrm{pH} 8.3,50 \mathrm{mmol} / \mathrm{l} \mathrm{KCl}, 2.5 \mathrm{mmol} / \mathrm{l}$ $\mathrm{MgCl}_{2}$ and 1 unit of Taq-Polymerase (Perkin-Elmer Applied Biosystems, Foster City, Calif., USA). The PCR included 35 cycles of $94^{\circ} \mathrm{C} / 56{ }^{\circ} \mathrm{C} / 72^{\circ} \mathrm{C}$, each for 1 min. Gel-purified PCR products were sequenced using the PRISM Ready Reaction dRhodamine-Terminator kit and an ABI Prism 310 Genetic Analyzer (Perkin-Elmer). For primer extension studies, total skeletal muscle RNA ( $1 \mu \mathrm{g})$ was reverse transcribed using the random-hexamer priming method. Aliquots of cDNA were subjected to PCR to generate a $377 \mathrm{bp}$ fragment. The forward 5 '-biotinylated exon 2 primer was 5'-TGGGCAGAGCCTTCCAGGAC-3' ( + 133 to + 152, GenBank Accession Nr. U84763) and the reverse exon 3 to exon 4 junction primer was 5'-CGGGTAGTGAGGCTGGAGTTGT-3' (+ 488 to +509$)$. The PCR reactions contained the reaction components described above and included 35 cycles of $94^{\circ} \mathrm{C} / 60^{\circ} \mathrm{C} /$ $72^{\circ} \mathrm{C}$, each for $1 \mathrm{~min}$. Transcripts of UCP1 and UCP2 were excluded to confound allele-specific studies, as $10 \mathrm{fg}$ of UCP1 or $\mathrm{UCP} 2$ template $\mathrm{CDNA}$ did not produce amplification products in the UCP3-specific PCR. We isolated ssDNA using streptavidin-coated magnetic beads (Dynal A. S., Oslo, Norway). Primers for wild-type and mutant allele-specific extension were $5^{\prime}$ GTACACCTGCTTGACGGA-3' $(+454$ to +471$)$ and $5^{\prime}$ TACACCTGCTTGACGGAG-3' ( + 453 to + 470), respectively. Extension reactions and quantification of extension products were done exactly as described [30]. For assay standardization, cDNAs of two patients, carrying either two wildtype or two mutant alleles were amplified using Pfu-Polymerase (Stratagene, La Jolla, Calif., USA) and blunt-end cloned using the ZERO-Background cloning system (Invitrogen, Carlsbad, Calif., USA). Various mixtures of plasmids containing the wild-type and mutant allele as inserts served as templates for PCR amplification and subsequent primer extension to generate a standard curve that compared molar ratios of templates with their signal intensity ratios.

Statistical analysis. Both ANOVA [31] and a more robust nonparametric test, the Kruskal Wallis test [32], were used to examine the equality of continuous variables such as age and biochemical measurements between obese and non-obese male or female subjects. A transformation was made on the original variable, if the equal variance and normality assumptions of the one-way ANOVA were rejected. For comparison of cate- gorical variables, a contingency chi-squared test was used. Agreement of genotype-frequencies with Hardy-Weinberg equilibrium was tested using a chi-squared goodness-of-fit test. The paired $t$-test was used to analyse UCP3 mRNA expression before and after weight reduction surgery. Multivariate regression analysis with sex and BMI as independent and leptin values as dependent variables was done in a large population including obese and normal subjects studied previously $[10,23,30,33]$ to predict plasma leptin concentrations in postobese subjects.

\section{Results}

The BMI of obese patients was almost twice that of control subjects in both sexes (Table 1). The average age of obese and non-obese men was similar but was lower in obese women than in non-obese women. In both sexes obese subjects had higher average plasma concentrations of insulin and leptin than control subjects whereas average glucose concentrations were similar in both groups. The RNase protection assays with the ${ }^{32} \mathrm{P}-\mathrm{UCP} 3_{\mathrm{L}}$ antisense RNA probe containing $174 \mathrm{nt}$ of exon 6 and $180 \mathrm{nt}$ of exon 7 showed two protected fragments consisting of $354 \mathrm{nt}$ and $174 \mathrm{nt}$, respectively. The larger fragment represented $\mathrm{UCP} 3_{\mathrm{L}}$ and the smaller $\mathrm{UCP}_{3}$ (Fig. 1). The average abundance of $U C P 3_{S}$ was about 2.5 times higher than that of $\mathrm{UCP} 3_{\mathrm{L}}$ in both obese and lean study subjects. Total $\mathrm{UCP} 3 \mathrm{mRNA}$ expression as well as that of $\mathrm{UCP} 3_{\mathrm{L}}$ and $\mathrm{UCP}_{\mathrm{S}}$, all corrected for cyclophilin mRNA abundance, were not different in lean and obese women, although the difference between lean and obese men approached statistical significance (Table 2). Median expression of UCP3 mRNA was also similar in obese and lean subjects, stratified by sex and no difference was observed between men and women. No significant difference in the molar ratio of $\mathrm{UCP}_{\mathrm{L}}$ to $\mathrm{UCP} 3_{\mathrm{S}}$ was noted in our study groups. An inverse association between total UCP3 mRNA and the molar $\mathrm{UCP} 3_{\mathrm{L}}$ to $\mathrm{UCP} 3_{\mathrm{S}}$ ratio was, however, observed in obese subjects only $(r=0.4829, n=38$, $p<0.005)$. Total UCP3 mRNA levels exhibited a correlation with plasma fatty acids in lean $(r=0.483$, $p<0.023$ ), but not in obese subjects.

Muscle UCP3 mRNA expression was determined in 7 of the 38 obese subjects 3 to 18 months after the gastric banding surgery. The BMI and plasma concentrations of leptin and insulin decreased between the surgical procedures, whereas no changes in plasma non-esterified fatty acid and glucose concentrations were noted (Table 3 ). A decrease in $\mathrm{UCP} 3_{\mathrm{L}}$ and $\mathrm{UCP}_{\mathrm{S}}$ mRNA expression was observed at the time of the second surgical procedure but molar transcript ratios of $\mathrm{UCP} 3_{\mathrm{L}}$ to $\mathrm{UCP} 3_{\mathrm{S}}$ remained unchanged (Fig.1, Table 3). To estimate the calorie intake status of these subjects at the time of the surgical procedures, plasma leptin concentrations were compared with those predicted from multivariate analysis 
Table 1. Characteristics of study subjects: the table shows, by sex, clinical and biochemical characteristics of obese and non-obese study subjects

\begin{tabular}{|c|c|c|c|c|c|c|}
\hline \multirow[t]{2}{*}{ Variable } & \multicolumn{3}{|l|}{ Women } & \multicolumn{3}{|l|}{ Men } \\
\hline & Obese & Non-obese & $p^{a}$ & Obese & Non-obese & $p^{\mathrm{a}}$ \\
\hline$n$ & 24 & 6 & & 14 & 9 & \\
\hline BMI $\left(\mathrm{kg} / \mathrm{m}^{2}\right)$ & $40.9 \pm 5.8$ & $24.2 \pm 3.6$ & & $44.4 \pm 12.2$ & $26.0 \pm 2.6$ & \\
\hline Age (years) & $34 \pm 11$ & $47 \pm 13$ & 0.0133 & $37 \pm 12$ & $47 \pm 12$ & NS \\
\hline Glucose $(\mathrm{mmol} / \mathrm{l})$ & $4.75 \pm 1.98$ & $4.30 \pm 0.62$ & NS & $4.43 \pm 0.83$ & $4.36 \pm 0.76$ & NS \\
\hline Insulin (pmol/1) & $9.4 \pm 7.2$ & $3.0 \pm 1.43$ & 0.0393 & $13.5 \pm 8.2$ & $5.7 \pm 3.0$ & 0.0136 \\
\hline Leptin (ng/ml) & $35.9 \pm 20.8$ & $5.8 \pm 2.4$ & 0.0016 & $34.9 \pm 31.1$ & $3.1 \pm 1.7$ & 0.0152 \\
\hline
\end{tabular}

Results represent proportions or means \pm SD. ${ }^{a}$ Analysis of variance within the respective sex group

Table 2. UCP3 mRNA expression in obese and lean women and men

\begin{tabular}{|c|c|c|c|c|c|c|}
\hline \multirow[t]{2}{*}{ Variable } & \multicolumn{3}{|l|}{ Women } & \multicolumn{3}{|l|}{ Men } \\
\hline & Obese & Non-obese & $\overline{p^{a}}$ & Obese & Non-obese & $p^{\mathrm{a}}$ \\
\hline$n$ & 24 & 6 & & 14 & 9 & \\
\hline $\mathrm{UCP}_{\mathrm{L}}$ total mRNA & $0.34 \pm 0.14$ & $0.27 \pm 0.14$ & 0.2592 & $0.32 \pm 0.10$ & $0.24 \pm 0.09$ & 0.0695 \\
\hline $\mathrm{UCP}_{\mathrm{S}}^{\mathrm{L}}$ total mRNA & $0.81 \pm 0.39$ & $0.67 \pm 0.27$ & 0.4136 & $0.87 \pm 0.38$ & $0.61 \pm 0.16$ & 0.0645 \\
\hline $\mathrm{UCP}_{\mathrm{L}} / \mathrm{UCP} 3_{\mathrm{S}}$ ratio & $0.46 \pm 0.15$ & $0.40 \pm 0.09$ & 0.3369 & $0.39 \pm 0.10$ & $0.40 \pm 0.12$ & 0.9019 \\
\hline
\end{tabular}

UCP3 mRNA expression was determined in skeletal muscle tissue samples of lean and obese human subjects using an RNase protection assay. UCP3 mRNA abundance was normalized for cyclophilin mRNA abundance.
Results are expressed as means \pm SD and represent mol UCP3 mRNA/mol cyclophilin mRNA or mol UCP $3_{\mathrm{L}} / \mathrm{mol} \mathrm{UCP} 3_{\mathrm{S}}$. ${ }^{a}$ Analysis of variance within the respective sex group
Table 3. Characteristics of obese and post-obese subjects

\begin{tabular}{lcc}
\hline Variables & Surgery I & Surgery II \\
\hline BMI $\left(\mathrm{kg} / \mathrm{m}^{2}\right)$ & $40.9 \pm 9.7$ & $30.6 \pm 9.2^{\mathrm{a}}$ \\
Glucose $(\mathrm{mmol} / \mathrm{l})$ & $4.7 \pm 1.0$ & $4.3 \pm 0.5$ \\
Insulin $(\mathrm{pmol} / \mathrm{l})$ & $13.7 \pm 12.8$ & $6.3 \pm 6.7^{\mathrm{b}}$ \\
Leptin $(\mathrm{ng} / \mathrm{ml})$ & $35.2 \pm 37.5$ & $9.7 \pm 16.2^{\mathrm{b}}$ \\
Fatty acids $(\mu \mathrm{mol} / \mathrm{l})$ & $0.846 \pm 0.264$ & $0.812 \pm 0.237$ \\
$\mathrm{UCP} 3$ mRNA & $1.07 \pm 0.52$ & $0.49 \pm 0.19^{\mathrm{b}}$ \\
$\mathrm{UCP} 3_{\mathrm{L}}$ mRNA & $0.35 \pm 0.16$ & $0.16 \pm 0.05^{\mathrm{b}}$ \\
$\mathrm{UCP} 3_{\mathrm{S}}$ mRA & $0.72 \pm 0.37$ & $0.33 \pm 0.14^{\mathrm{b}}$ \\
$\mathrm{UCP}_{\mathrm{L}} / \mathrm{UCP} 3_{\mathrm{S}}(\mathrm{mol} / \mathrm{mol})$ & $0.50 \pm 0.09$ & $0.49 \pm 0.10$
\end{tabular}

Clinical and biochemical characteristics of 5 female and 2 male subjects before and after weight reducing surgery are shown. Surgery I refers to the initial weight reduction surgery and surgery II refers to an elective surgical procedure done $9 \pm 5$ months later.

UCP3 mRNA expression is shown as $\mathrm{mol} / \mathrm{mol}$ cyclophilin mRNA.

${ }^{\mathrm{a}} p<0.0001,{ }^{\mathrm{b}} p<0.05$, paired $t$-test

in a group of 497 subjects at their usual weight with BMIs ranging from 17.5 to 64.3 . Body mass index and sex accounted for $61 \%$ of the variance of leptin in this group. In our seven patients, the average (SD) leptin was $81(30) \%$ of that predicted at the initial weight reducing surgery but was decreased to 28 $(14) \%(p<0.01)$ of that predicted at the second surgical procedure, strongly suggesting hypocaloric intake in the post-obese state. Muscle UCP3 mRNA expression was also measured in ten post-obese women from whom muscle biopsies had only been obtained during the second elective surgery. The
BMI in these patients had decreased from $44.7 \pm 4.2$ to $30.9 \pm 4.6 \mathrm{~kg} / \mathrm{m}^{2}$ over a period of $34 \pm 19$ months. Expression of $\mathrm{UCP}_{\mathrm{L}}$ and $\mathrm{UCP} 3_{\mathrm{S}}$ was $0.17 \pm 0.05$ and $0.38 \pm 0.14 \mathrm{~mol} / \mathrm{mol}$ cyclophilin mRNA, respectively. These values differed from the UCP3 expression in lean $(p<0.05)$ and obese women $(p<0.005)$ shown in Table 2 . The measured leptin in these subjects was $66(27) \%$ of that predicted. Thus, the decline in muscle UCP3 expression in both study groups cannot be attributed to the post-obese state per se, but could reflect a prolonged hypocaloric intake.

To estimate the contribution of the UCP3 gene locus to the interindividual variability of UCP3 mRNA expression (Table 2), we measured allele-specific mRNA expression in subjects heterozygous for a silent T/C polymorphism at position +297 relative to the translation start site (Fig. 2). The estimated frequencies of the $\mathrm{T}$ and $\mathrm{C}$ alleles in our study group were 0.798 and 0.202 , respectively. The observed genotype frequencies agreed with Hardy-Weinberg expectations. Using mixtures consisting of different molar ratios of wild-type and variant cDNA, a linear relation $(r=0.96, p<0.001)$ was found between molar input ratios and signal intensity ratios of extension products (Fig. 2C). The coefficient of variation, determined in equimolar mixtures of wild-type and variant templates, was $4 \%$. Thus, primer extension allowed reliable quantitation of mRNA species transcribed from the two UCP3 alleles. In only one obese subject, the wild-type to variant transcript abundance ratio of 1.17 exceeded the threefold assay variability. In the 
A

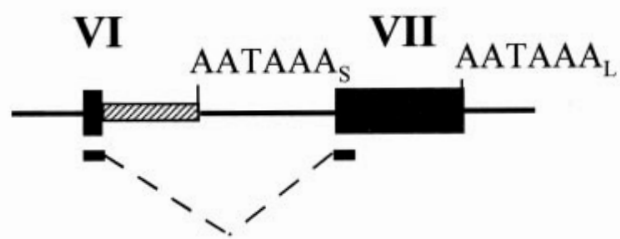

B

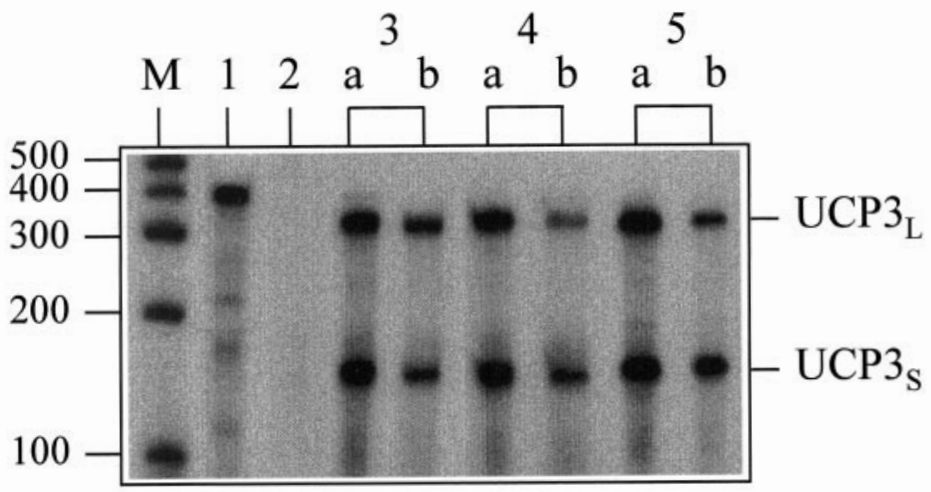

C

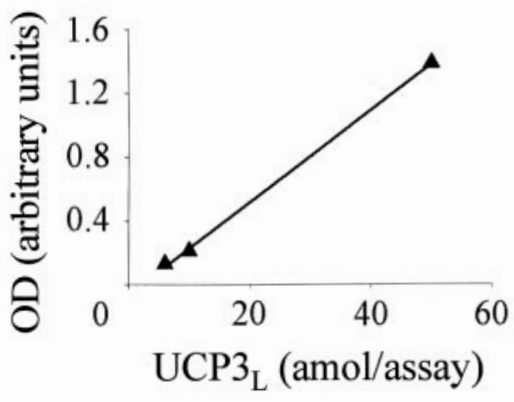

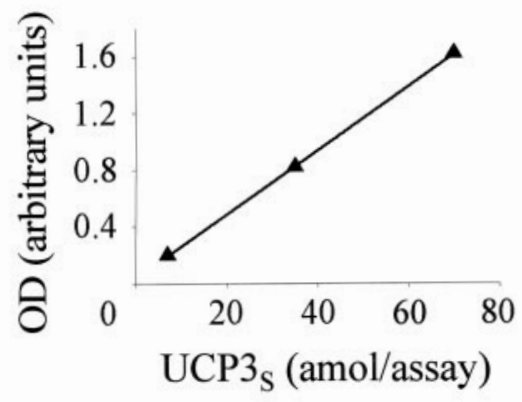

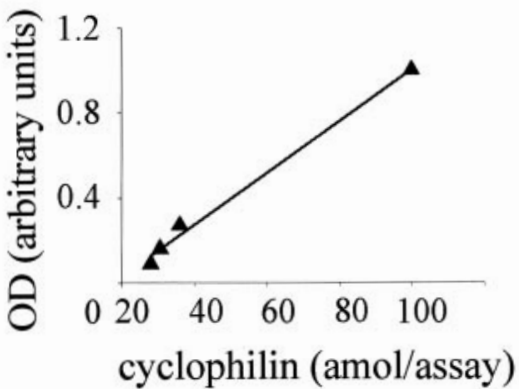

Fig. 1A-C. Quantification of $\mathrm{UCP}_{\mathrm{L}}$ and $\mathrm{UCP} 3_{\mathrm{S}} \mathrm{mRNA}$ by RNase protection assay in skeletal muscle before and after weight loss. A Structural relation of antisense probe complementary to exon 6 and 7 sequences with $\mathrm{UCP}_{\mathrm{L}}$ and $\mathrm{UCP} 3_{\mathrm{S}}$ mRNA structure; AATAAA $_{S}$ and AATAAA $_{L}$ refer to previously described polyadenylation signals used for the generation of $\mathrm{UCP}_{\mathrm{L}}$ and $\mathrm{UCP} 3_{\mathrm{S}}$ mRNA. The hatched box indicates intron 6 sequences present in $\mathrm{UCP} 3_{\mathrm{S}}$ mRNA. B Autoradiograph of RNase protection assay; $\mathrm{M}$, end-labelled size marker containing the number of nucleotides indicated; 1 , undigested ${ }^{32} \mathrm{P}-\mathrm{UCP} 3$ antisense probe; $2,{ }^{32} \mathrm{P}-\mathrm{UCP} 3$ antisense probe hybridized to yeast RNA and subjected to RNase digestion; 3-5, RNase protection assay of $10 \mu \mathrm{g}$ of skeletal muscle total RNA from three obese subjects before (a) and after (b) weight loss subsequent to the gastric banding procedure. Protected fragments representing $\mathrm{UCP} 3_{\mathrm{L}}$ and $\mathrm{UCP} 3_{\mathrm{S}}$ mRNA are indicated on the right. RNase protection assays using a cyclophilin antisense mRNA was used for UCP3 mRNA normalization (lower panel). C Standardization of RNase protection assays using increasing amounts of ${ }^{3} \mathrm{H}$-labelled $\mathrm{UCP}_{\mathrm{L}}$ (left), $\mathrm{UCP}_{\mathrm{S}}$ (middle) and cyclophilin sense RNA (right). Molar input of sense RNA was plotted against optical density (OD) values determined by scanning autoradiographs

remaining subjects, 16 obese, 1 post-obese and 5 nonobese, displaying UCP3 mRNA abundance between 0.36 and $1.79 \mathrm{~mol} / \mathrm{mol}$ cyclophilin mRNA, the average molar ratio of wild-type to variant transcript was 0.97 (SD 0.03, range 0.89-1.06). Thus, the small devi- ation from unity in the transcript ratio of some subjects was within the analytical variation. Minor differences in allele-specific expression can therefore not be excluded.

\section{Discussion}

A large portion of the variance in resting energy expenditure among humans has been accounted for by differences in fat-free mass, much of which consists of skeletal muscle [34]. Because of its abundant expression in skeletal muscle, UCP3 is a potential candidate for the proton leak that might contribute appreciably to resting metabolic rate and total energy expenditure. Similar expression of UCP3 mRNA have been reported in muscle tissues of obese and lean people [24]. Although our gender-specific analyses showed marginally higher expression in morbidly obese than in lean men, our findings generally support these earlier results [24] and argue against abnormalities in UCP3 mRNA expression in obese subjects. An altered protein or activity level of UCP3 in obesity cannot, however, be excluded as translational and post-tranlational events could vary and the concentration of metabolites activating or inhibiting uncoupling activity could differ between obese and 


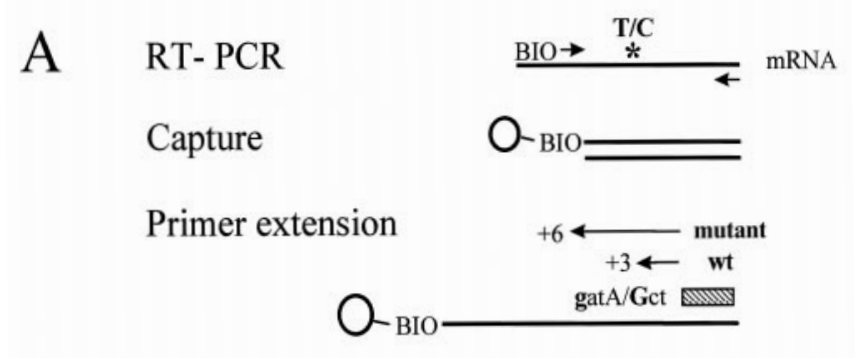

B

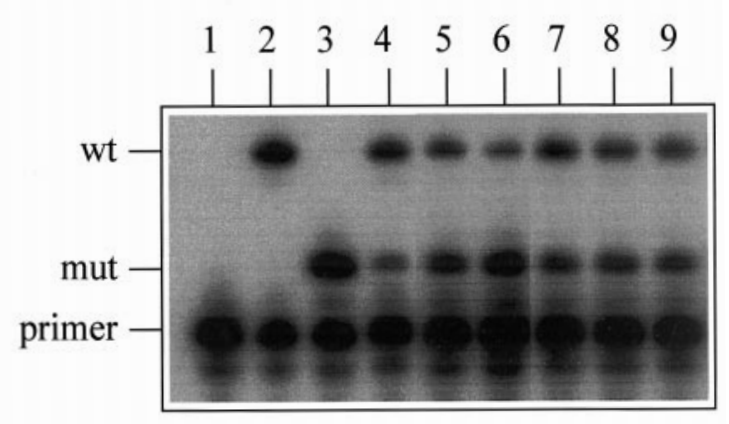

C

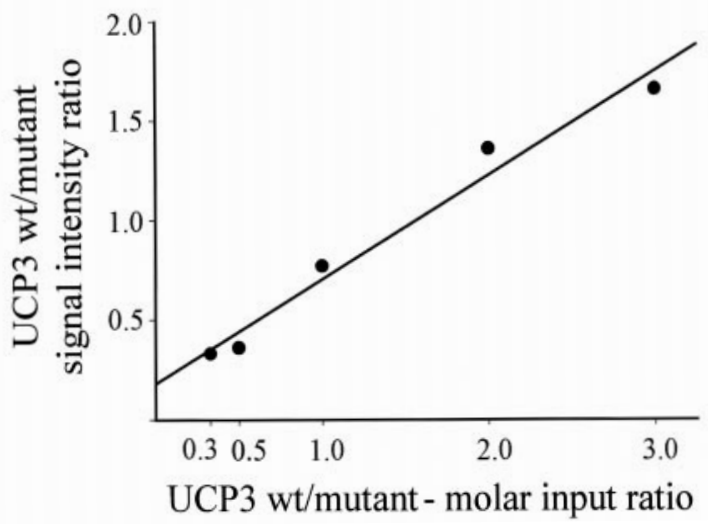

Fig. 2A-C. UCP3 allele-specific expression studies using variant-specific primer extension. A Experimental strategy showing use of a biotinylated sense primer for RT-PCR (top), capture of the amplified UCP3 sense strand via streptavidin beads (middle) and primer extension using ddGTP (bottom). Arrows indicate the extension products predicted for wildtype and mutant templates. B Autoradiogram of primer extension products as schematized in A. Lanes $1-9$ show ${ }^{32} \mathrm{P}$-labelled primer, extension products of cloned wild-type and variant cDNA, mixtures of wild-type and variant cDNA in molar ratios of 3,1 , and 0.33 , respectively, skeletal muscle total RNA from two obese subjects and DNA of a subject heterozygous for the T/C substitution in exon 3. C Standard curve of the primer extension assay constructed by analysing five different mixtures of cloned UCP3 wild-type and variant alleles $(r=0.96, p<0.001)$. The slope and intercept of the regression line was 0.53 and 0.18 , respectively. Molar input ratios were plotted against signal intensity ratios determined by scanning autoradiographs lean humans. Nevertheless, the similar UCP3 mRNA expression in muscle of lean and obese subjects is consistent with studies showing that resting metabolic rate and total energy expenditure per unit of fat-free body mass are similar in lean and obese subjects [35].

Our study shows that $\mathrm{UCP} 3_{\mathrm{L}}$ was the less abundant transcript species in all subjects studied. This result is at variance with another study showing equimolar abundance of $\mathrm{UCP} 3_{\mathrm{L}}$ and $\mathrm{UCP} 3_{\mathrm{S}}$ in obese and lean subjects [26]. Consistent with the study of Millet et al. [24], the molar ratio of $\mathrm{UCP}_{\mathrm{L}}$ to $\mathrm{UCP} 3_{\mathrm{S}}$ was similar in all study groups (Fig. 1, Tables 2, 3) suggesting no alteration in transcript processing in obese subjects. The moderate inverse association, observed within the obese group only, between UCP3 mRNA abundance and molar transcript ratio suggests a saturable process of $\mathrm{UCP} 3_{\mathrm{L}}$ generation.

To gain further insight into a possible role of UCP3 in human energy homeostasis, we determined mRNA expression in subjects who experienced a substantial weight loss after the gastric banding surgery. The decrease of UCP3 transcripts observed in post-obese subjects probably reflected prolonged hypocaloric intake, since the plasma leptin concentrations in these patients were lower than those predicted for their BMI. Such a conclusion would be consistent with recent studies showing a reduction of energy expenditure during or after weight loss [36, 37]. Prospective data in Pima Indians established an association of hypoleptinaemia with future weight gain [38]. The subnormal leptin concentrations in our post-obese subjects could have resulted from a defect in the regulation of leptin rather than from a hypocaloric diet but the similarity of measured and predicted leptin in these patients prior to the weight reducing surgery is an argument against this suggestion. Nevertheless, the model of leptin prediction included obese subjects perhaps defective in adequate upregulation of leptin expression. Hence, the possibility cannot be excluded that obesity with its attendant metabolic changes enhanced UCP3 mRNA expression in some subjects, thereby masking inherent defects in UCP3 expression.

Expression of UCP3 mRNA in muscle of obese and lean subjects was augmented in response to a 5-day calorie restriction [24]. Fasting for 24 or $48 \mathrm{~h}$ increased, but a $50 \%$ food restriction for 1 week decreased muscle UCP3 mRNA abundance in rats [15, 39]. Hence, changes in metabolite concentrations related to the duration of food restriction could be critical determinants of UCP3 gene expression. Fatty acids have been suspected to influence UCP3 gene expression [40]. In our study, plasma fatty acid concentration displayed a moderate correlation with UCP3 mRNA abundance in lean subjects only and plasma fatty acid concentrations were similar in obese patients before and after weight reduction. Thus, additional factors need to be invoked to ex- 
plain the downregulation of UCP3 expression in our post-obese patients. In obese subjects, weight loss caused by a prolonged low-calorie diet enhanced muscle dynamic endurance, improved the fractional velocity of contraction and reduced the rate of glucose oxidation [41]. In addition, UCP3 and UCP2 expression decreased in response to endurance training in rats [42]. Thus, the need for a higher metabolic efficiency as exemplified by prolonged calorie restriction or endurance training might be conducive to downregulation of muscle UCP3 expression which would be predicted to reduce energy dissipation in these tissues.

Since muscle UCP3 mRNA abundance displayed considerable variability among subjects, we determined whether cis-regulatory elements would account for part of this variability. Such an approach was used previously to show that sequence variations at the UCP1 gene locus accounted for a large portion of the mRNA expression variance in obese subjects [30]. Only one of 23 subjects, however, displayed an allelic difference in UCP3 mRNA abundance. Differences in trans-acting factor activities must therefore have accounted for most of the interindividual variability in UCP3 mRNA expression and differences in cis-regulatory elements must have played a minor part. We have sequenced the UCP3 promoter and identified, by computational analyses, consensus sequences for trans-acting factor binding sites including three clustered E-box motifs, a peroxisome proliferator-activated receptor $\gamma /$ retinoid $\mathrm{X}$ receptor response element and a thyroid response element (Esterbauer $\mathrm{H}$, Oberkofler H, Patsch W, unpublished observation).

In summary, our studies suggest that human obesity is not associated with alterations of UCP3 mRNA expression or transcript processing. Sequence substitutions at the UCP3 gene locus affecting its mRNA expression in muscle are probably uncommon in the Austrian population. The reduction in muscle UCP3 mRNA expression that occurred in our postobese patients could contribute to the reduced energy expenditure that has been reported after prolonged fasting [36, 37].

Acknowledgements. The technical assistance of C. Winkler and J. Roth is gratefully acknowledged. This study was supported by a grant from the Medizinische Forschungsgesellschaft Salzburg and by the Jubliaeumsfondsprojekt Nr.7228 from the Oesterreichische Nationalbank.

\section{References}

1. Ravussin E, Lillioja S, Knowler WC et al. (1988) Reduced rate of energy expenditure as a risk factor for body-weight gain. N Engl J Med 318: 467-472

2. Griffiths M, Payne PR, Stunkard AJ, Rivers JP, Cox M (1990) Metabolic rate and physical development in children at risk of obesity. Lancet 336: 76-78
3. Bogardus C, Lillioja S, Ravussin E et al. (1986) Familial dependence of the resting metabolic rate. N Engl J Med 315: 96-100

4. Bouchard C, Tremblay A, Nadeau A et al. (1989) Genetic effect in resting and exercise metabolic rates. Metabolism 38: 364-370

5. Himms-Hagen J (1989) Brown adipose tissue thermogenesis and obesity. Prog Lipid Res 28: 67-115

6. Ricquier D, Casteilla L, Bouillaud F (1991) Molecular studies of the uncoupling protein. FASEB J 5: 2237-2242

7. Lowell BB, S-Susulic V, Hamann A et al. (1993) Development of obesity in transgenic mice after genetic ablation of brown adipose tissue. Nature 366: 740-742

8. Kopecky J, Clarke G, Enerback S, Spiegelman B, Kozak LP (1995) Expression of the mitochondrial uncoupling protein gene from the aP2 gene promoter prevents genetic obesity. J Clin Invest 96: 2914-2923

9. Krief S, Lonnqvist F, Raimbault S et al. (1993) Tissue distribution of beta 3 -adrenergic receptor mRNA in man. J Clin Invest 91: 344-349

10. Oberkofler H, Dallinger G, Liu YM, Hell E, Krempler F, Patsch W (1997) Uncoupling protein gene: quantification of expression levels in adipose tissues of obese and nonobese humans. J Lipid Res 38: 2125-2133

11. Gimeno RE, Dembski M, Weng X et al. (1997) Cloning and characterization of an uncoupling protein homolog: a potential molecular mediator of human thermogenesis. Diabetes 46: 900-906

12. Fleury C, Neverova M, Collins S et al. (1997) Uncoupling protein-2: a novel gene linked to obesity and hyperinsulinemia. Nat Genet 15: 269-272

13. Vidal-Puig A, Solanes G, Grujic D, Flier JS, Lowell BB (1997) UCP3: an uncoupling protein homologue expressed preferentially and abundantly in skeletal muscle and brown adipose tissue. Biochem Biophys Res Commun 235: 79-82

14. Boss O, Samec S, Paoloni-Giacobino A et al. (1997) Uncoupling protein-3: a new member of the mitochondrial carrier family with tissue-specific expression. FEBS Lett 408: $39-42$

15. Gong DW, He Y, Karas M, Reitman M (1997) Uncoupling protein-3 is a mediator of thermogenesis regulated by thyroid hormone, beta3-adrenergic agonists, and leptin. J Biol Chem 272: 24129-24132

16. Astrup A, Bulow J, Christensen NJ, Madsen J, Quaade F (1986) Facultative thermogenesis induced by carbohydrate: a skeletal muscle component mediated by epinephrine. Am J Physiol 250:E226-E229

17. Thurlby PL, Ellis RD (1986) Differences between the effects of noradrenaline and the beta-adrenoceptor agonist BRL 28410 in brown adipose tissue and hind limb of the anaesthetized rat. Can J Physiol Pharmacol 64: 1111-1114

18. Solanes G, Vidal-Puig A, Grujic D, Flier JS, Lowell BB (1997) The human uncoupling protein-3 gene. Genomic structure, chromosomal localization, and genetic basis for short and long form transcripts. J Biol Chem 272: 25433-25436

19. Boss O, Giacobino JP, Muzzin P (1998) Genomic structure of uncoupling protein-3 (UCP3) and its assignment to chromosome 11q13. Genomics 47: 425-426

20. Bouchard C, Perusse L, Chagnon YC, Warden C, Ricquier D (1997) Linkage between markers in the vicinity of the uncoupling protein 2 gene and resting metabolic rate in humans. Hum Mol Genet 6: 1887-1889

21. Warden CH, Fisler JS, Shoemaker SM et al. (1995) Identification of four chromosomal loci determining obesity in a multifactorial mouse model. J Clin Invest 95: 1545-1552 
22. Hashimoto L, Habita C, Beressi JP et al. (1994) Genetic mapping of a susceptibility locus for insulin-dependent diabetes mellitus on chromosome 11 q. Nature 371: 161-164

23. Oberkofler H, Liu YM, Esterbauer H, Hell E, Krempler F, Patsch W (1998) Uncoupling protein-2 gene: reduced mRNA expression in intraperitoneal adipose tissue of obese humans. Diabetologia 41: 940-946

24. Millet L, Vidal H, Andreelli F et al. (1997) Increased uncoupling protein-2 and -3 mRNA expression during fasting in obese and lean humans. J Clin Invest 100: 2665-2670

25. Jezek P, Orosz DE, Modriansky M, Garlid KD (1994) Transport of anions and protons by the mitochondrial uncoupling protein and its regulation by nucleotides and fatty acids. A new look at old hypotheses. J Biol Chem 269: 26184-26190

26. Millet L, Vidal H, Larrouy D, Andreelli F, Laville M, Langin D (1998) mRNA expression of the long and short forms of uncoupling protein-3 in obese and lean humans. Diabetologia 41: 829-832

27. Chomczynski P, Sacchi N (1987) Single-step method of RNA isolation by acid guanidinium thiocyanate-phenolchloroform extraction. Anal Biochem 162: 156-159

28. Haendler B, Hofer-Warbinek R, Hofer E (1987) Complementary DNA for human T-cell cyclophilin. EMBO J 6: 947-950

29. Urhammer SA, Dalgaard LT, Sorensen TI et al. (1998) Organisation of the coding exons and mutational screening of the uncoupling protein 3 gene in subjects with juvenileonset obesity. Diabetologia 41: 241-244

30. Esterbauer H, Oberkofler H, Liu YM et al. (1998) Uncoupling protein-1 mRNA expression in obese human subjects: the role of sequence variations at the uncoupling protein-1 gene locus. J Lipid Res 39: 834-844

31. Neter J, Kutner CJ, Nachtsheim CJ, Wasserman W (1996) Applied Linear Statistical Methods. Irwin, Chicago, Ill.
32. Daniel WW (1990) Applied Nonparametric Statistics. PWS-Kent Publishing, Boston

33. Krempler F, Hell E, Winkler C, Breban D, Patsch W (1998) Plasma leptin levels: interaction of obesity with a common variant of insulin receptor substrate-1. Arterioscler Thromb Vasc Biol 18: 1686-1690

34. Zurlo F, Larson K, Bogardus C, Ravussin E (1990) Skeletal muscle metabolism is a major determinant of resting energy expenditure. J Clin Invest 86: 1423-1427

35. Rosenbaum M, Leibel RL, Hirsch J (1997) Obesity. N Engl J Med 337: 396-407

36. Leibel RL, Rosenbaum M, Hirsch J (1995) Changes in energy expenditure resulting from altered body weight. $\mathrm{N}$ Engl J Med 332: 621-628

37. Weigle DS, Sande KJ, Iverius PH, Monsen ER, Brunzell JD (1988) Weight loss leads to a marked decrease in nonresting energy expenditure in ambulatory human subjects. Metabolism 37: 930-936

38. Ravussin E, Pratley RE, Maffei M et al. (1997) Relatively low plasma leptin concentrations precede weight gain in Pima Indians. Nat Med 3: 238-240

39. Boss O, Samec S, Kuhne F et al. (1998) Uncoupling protein-3 expression in rodent skeletal muscle is modulated by food intake but not by changes in environmental temperature. J Biol Chem 273: 5-8

40. Weigle DS, Selfridge LE, Schwartz MW et al. (1998) Elevated free fatty acids induce uncoupling protein 3 expression in muscle: a potential explanation for the effect of fasting. Diabetes 47: 298-302

41. Krotkiewski M, Grimby G, Holm G, Szczepanik J (1990) Increased muscle dynamic endurance associated with weight reduction on a very-low-calorie diet. Am J Clin Nutr 51: 321-330

42. Boss O, Samec S, Desplanches D et al. (1998) Effect of endurance training on mRNA expression of uncoupling proteins 1,2 , and 3 in the rat. FASEB J 12: 335-339 